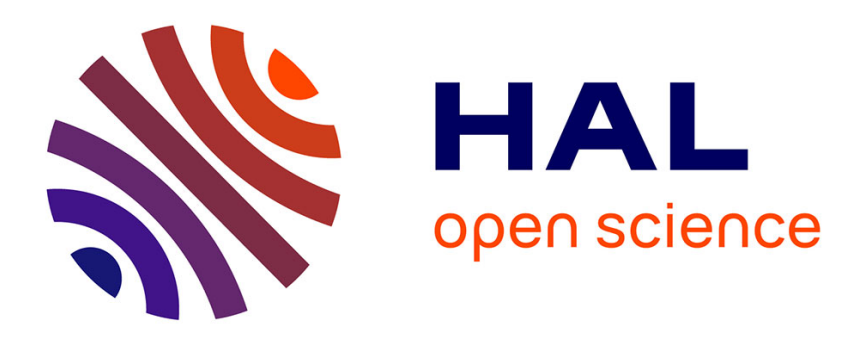

\title{
Interpretation of very long-term basic creep tests of concrete
}

\author{
Jean Michel Torrenti
}

\section{To cite this version:}

Jean Michel Torrenti. Interpretation of very long-term basic creep tests of concrete. European Journal of Environmental and Civil Engineering, 2019, 23 (5), 11 p. 10.1080/19648189.2018.1454862 . hal02469641

\section{HAL Id: hal-02469641 \\ https://hal.science/hal-02469641}

Submitted on 6 Feb 2020

HAL is a multi-disciplinary open access archive for the deposit and dissemination of scientific research documents, whether they are published or not. The documents may come from teaching and research institutions in France or abroad, or from public or private research centers.
L'archive ouverte pluridisciplinaire HAL, est destinée au dépôt et à la diffusion de documents scientifiques de niveau recherche, publiés ou non, émanant des établissements d'enseignement et de recherche français ou étrangers, des laboratoires publics ou privés. 


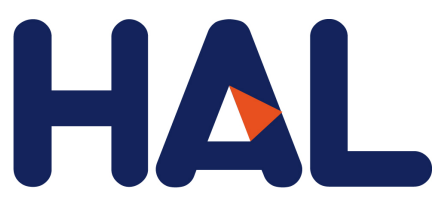

archives-ouvertes

\title{
Interpretation of very long-term basic creep tests of concrete
}

\author{
Jean Michel Torrenti
}

\section{To cite this version:}

Jean Michel Torrenti. Interpretation of very long-term basic creep tests of concrete. European journal of environmental and civil engineering/Revue européenne de génie civil, 2019, 23 (5), 11 p. 10.1080/19648189.2018.1454862 . hal-02469641

\section{HAL Id: hal-02469641 \\ https://hal.archives-ouvertes.fr/hal-02469641}

Submitted on 6 Feb 2020

HAL is a multi-disciplinary open access archive for the deposit and dissemination of scientific research documents, whether they are published or not. The documents may come from teaching and research institutions in France or abroad, or from public or private research centers.
L'archive ouverte pluridisciplinaire HAL, est destinée au dépôt et à la diffusion de documents scientifiques de niveau recherche, publiés ou non, émanant des établissements d'enseignement et de recherche français ou étrangers, des laboratoires publics ou privés. 


\section{Interpretation of very long term basic creep tests of concrete}

The prediction of very long term delayed deformation of concrete is particularly important for prestressed structures. This deformation has a number of components, one of which is basic creep, which is the deformation of the concrete under loading, in the absence of any exchange of water with the environment. Analysis of experimental results shows that this component can be expressed as a logarithmic function of time. However, some very long term tests seem to show a deviation from this trend. The aim of this article is to demonstrate that these deviations can be explained by experimental artefacts (either parasitic drying or leaching of the concrete).

Keywords: Concrete, basic creep, experiment, drying, leaching

\section{Introduction}

Predicting very long term delayed deformation in concrete is particularly important for prestressed structures such as bridges or nuclear power plant vessels because it can affect their service life. Analysis of the behaviour of this type of structure shows that delayed deformations are not asymptotic (Bažant, Hubler and Yu, 2011), (Sellin, Bathélémy, Torrenti and Bondonnet 2014), (Benboudjema and Torrenti 2015). The delayed deformation of these structures results from the relaxation of the steel and the delayed deformation of the concrete. Conventionally, despite the fact that coupling between autogenous shrinkage and basic creep or drying shrinkage and drying creep are known (Ulm et al., 1999) (Benboudjema et al., 2005), the delayed strains are conventionally broken down into autogenous shrinkage, desiccation shrinkage, basic creep and desiccation creep.

The consensus with regard to basic creep seems to be that the compliance, which consists of both the elastic deformation and the basic creep deformation, can be expressed in the following way: 


$$
J\left(t_{0}, t-t_{0}\right)=\frac{1}{E\left(t_{0}\right)}+\frac{1}{\beta_{1} C} \log \left(1+\frac{t-t_{0}}{\beta_{2} \tau\left(t_{0}\right)}\right)
$$

where $t_{0}$ is the age of loading, $E$ is the Young's modulus, $C$ is a parameter which is independent of $t_{0}, \tau$ is a time depending on $t_{0}$, and $\beta_{1}$ and $\beta_{2}$ are adjusted parameters with default values equal to 1 while $\mathrm{C}$ and $\tau\left(t_{0}\right)$ are estimated using relations proposed in the fib model code 2010 (Muller et al., 2013). These parameters are adjusted to experimental results in order to minimize the measured strains to the predicted ones. A comparison with some experimental data shows values between 0,2 and 1 for $\beta_{1}$ and between 300 and 0,2 for $\beta_{2}$ depending on the type of concrete and on the age of loading for the second parameter (Torrenti and Le Roy, 2017).

This relationship, which is similar to that proposed for the fib Model Code 2010 (Muller et al., 2013), has been compared with many experimental results and provides an accurate representation of the behaviour observed in most of the available tests (Le Roy, F. Le Maou and J.M. Torrenti, 2017), (Torrenti and Le Roy, 2017). However, in the very long term (after 1000 days), some experimental results seem to deviate from this relationship, exhibiting deformation that is greater than that predicted by Equation 1: in Leroy's tests in which loading was applied at 28 days and continued for 10 years, there is a disparity between the value predicted by Equation 1 and the measurements (see figure 1) and in Brooks' tests. that lasted for 30 years an acceleration of deformation with respect to the logarithm of time appears in the very long term, especially for the highest W/C ratios (see Figure 2). The aim of this article is to analyse the possible causes of this deviation that result from the material itself: we assume that the system maintains a constant load and that the deformation measurement system is not responsible. In addition, in the case of basic creep, the possible effect of carbonation shrinkage is not considered (this will be different in the case of drying creep. Houst (97) 
has shown that the carbonation shrinkage could be larger than $1000 \mu \mathrm{m} / \mathrm{m}$ on cement pastes).

Figure 1. Basic creep: concrete B2 (W/C = 0.33) loaded after 1, 3, 7 and 28 days (Le Roy, F. Le Maou and J.M. Torrenti, 2017). Comparison between experimental results and modelling with equation 1 (solid lines).

Figure 2. Specific basic creep: Brooks' tests, North Notts aggregates (Brooks, 2005). Comparison between experimental results and modelling with equation 1 (solid lines).

\section{An intrinsic cause?}

If a parasitic phenomenon is not involved (see the paragraphs below), the acceleration in the basic creep may be due to an intrinsic phenomenon, for example a redistribution of C-S-H stresses to aggregates leading to nonlinearities (Šmilauer, Leps and Gregorova, 2013) or creep damage coupling linked to creep-induced microcracking (Rossi et al., 2012 ), (Torrenti et al., 2008), (Torrenti, 2017). Using Brooks’ tests, Šmilauer explains this behaviour by an over-stressing of the cement paste and interfacial transition zone around aggregates caused by a redistribution of the load from the creeping cement paste to the stiffer non-creeping aggregates. For Rossi, using creep tests performed in sealed conditions, basic creep is the result of micro-cracking that creates a supplementary self-desiccation and induces a supplementary strain when compared to autogenous shrinkage. For both approaches, it is possible to calibrate the parameters of the models in order to obtain this acceleration with the same timescale than the experiments. However, classical creep tests are performed on a period that is shorter than 1000 days meaning that the fitting of the parameters for the coupled phenomenon on the long term will be impossible. And, in real structures, this acceleration is not apparent: overall behaviour seems to follow a logarithmic evolution 
with time on period larger than 30 years at least - see (Bažant, Hubler, Yu, 2011) or (Batehelemy et al., 2015) for bridges and (Benboudjema et Torrenti, 2015) for nuclear power plants.. It is therefore important to assess whether or not the observed behaviour is an artefact.

\section{A defect in the basic creep test?}

When carrying out a basic creep test, two main approaches are applied in order to prevent the concrete from drying: the test pieces are either covered with a sealing layer or kept in water. In the RILEM database (Hubler et al., 2015) for instance where these two conditions are corresponding to basic creep tests. It should be noted that these two test conditions are not equivalent. For low water-to-cement ratios in particular therefore for high strength and very high strength concretes - self-desiccation due to hydration reactions leads to internal moisture levels that are as low as 75\% (Yssorche and Ollivier, 1999), which can limit hydration (Flatt, G.W. Scherer, J.W. Bullard, 2011). However, obviously, in the case of storage in water, the porosity of concrete is filled with water (saturation equal to 1), the relative humidity remains at $100 \%$ and hydration could continue. Shrinkage is also affected by these two different conditions (swelling is observed under water for instance in Brooks' tests) and the final results for basic creep are certainly different and not exactly comparable. And because of the couplings between autogenous shrinkage and basic creep (Ulm et al., 1999) (Aili et al., 2018) there is certainly an influence of the evaluation of basic creep. The phenomena that may affect long term behavior in both cases are also different and are examined.

\section{Test with a sealing coating}

In this test, the specimens are protected from desiccation by a surface coating. Several techniques are possible such as the application of a resin or self-adhesive aluminum 
sheets, or even a combination of both. However, maintaining tightness over a long period of time still poses serious difficulties (Attolou, Belloc and Torrenti, 1989). In the case of two layers of self-adhesive aluminum, (Toutlemonde and Le Maou, 1999) found that water loss accelerates over time and measured a loss of mass of approximately $0.4 \%$ after about 2 years. Recent results confirm that avoiding completely drying in a shrinkage or creep test with a long duration is still very difficult (Charpin et al., 2018).

Creep is the result of the difference between total deformation and shrinkage. So, if shrinkage is measured at the same time as creep and the test pieces have the same protection for both tests, the subtraction eliminates any autogenous deformation (drying shrinkage if drying occurs). But very often the autogenous shrinkage test is stopped before the end of the creep test. This was the case for Le Roy's tests (Le Roy, F. Le Maou and J.M. Torrenti, 2017), where the autogenous shrinkage test was stopped after 1300 days while the creep tests were continued for more than 5000 days. Also, due to drying, the results of the basic creep test are affected by a proportion of the drying creep. The difference that can be seen in figure 1 between a logarithmic relationship and the measurements is of the order of $410^{-6} / \mathrm{MPa}$ (for a period between 1000 days and 5000 days approximately) and this value is compatible with deformation due to drying shrinkage and desiccation creep. For drying shrinkage only, at a relative humidity of $50 \%$ and for a concrete mean strength of $40 \mathrm{MPa}$, the amplitude is around $300 \mu \mathrm{m} / \mathrm{m}$. If we assume that the mass loss is only $10 \%$ of the final value the drying shrinkage is around $30 \mu \mathrm{m} / \mathrm{m}$. if the applied stress in the creep test is $10 \mathrm{MPa}$, the effect of drying shrinkage will be $3 \mu \mathrm{m} / \mathrm{m} / \mathrm{MPa}$ which is close to the observed deviation.

\section{Test with storage of the samples under water}

In this type of test, the specimens are stored in a water tank. The observed acceleration cannot therefore be due to drying. On the other hand, conservation in water can result in 
the progressive leaching of hydrates, beginning with portlandite and followed by C-S-H. Of course, this phenomenon is very slow and is not noticeable in a very short test. Similarly, if the water is not changed, it becomes saturated with calcium and leaching slows down greatly. Brooks article, unfortunately, do not mention if the water was changed. However, through personal contacts with Professor Forth (who works in the same laboratory as Brooks) we have established that the water in the basic creep tests was changed every 3 months or so. Since the specimens in Brooks' tests were cylinders with a slenderness equal to two and a radius of only $38 \mathrm{~mm}$, leaching is therefore certain to have occurred on a significant part of the samples. And, indeed, at the end of the creep tests, Brooks has measured the compressive strength of the samples that were used for the creep tests and the strengths of the samples used for basic creep were $30 \%$ lower than the ones of the samples used for drying creep. This is an indication of the effect of leaching (even if the Young's modulus of the basic creep samples was larger than the one of drying creep samples which should not be the case if leaching occured). If leaching is assumed, coupling with the creep exists (Torrenti et al., 2008) and it has a major impact.

To estimate this effect, we have assumed that the leached zone does not sustain stresses (hypothesis of total damage) and therefore no longer plays a role in the mechanical equilibrium of the cross-section. In fact, when concrete is leached there is a strong reduction of the strength and the behaviour is becoming more plastic (Nguyen et al., 2007). The consequence is that during a progressive leaching, if a sample is loaded, the stresses sustained by the leached part are very limited. If these stresses are neglected, when the material leaches, the stress applied to the core material increases, which results in apparent nonlinearity of the creep and possibly, when the leached depth becomes very great, in nonlinearity due to coupling with damage (Torrenti et al., 2008). 
If the leached depth $\mathrm{x}_{\mathrm{d}}$ is expressed by the following equation (which could be considered valid only if the degraded depth is lower than the radius of the sample):

$$
x_{d}=k \sqrt{t}
$$

the stress applied to the core material changes as follows:

$$
\sigma(t)=\sigma\left(t_{0}\right) \frac{\pi R^{2}}{\pi(R-k \sqrt{t})^{2}}
$$

where $\mathrm{R}$ is the radius of the sample and $\sigma\left(t_{0}\right) \pi R^{2}$ is the force applied to the sample, which is assumed to be constant. Using equation 1 to establish the creep and applying the principle of superposition to take account the change in stress, the effect of leaching may be modelled:

$$
\varepsilon\left(t, t_{0}\right)=\int_{t_{0}}^{t} J(\tau, t-\tau) d \sigma(\tau)
$$

where $\tau$ is the time when a stress variation is considered. Kamali et al. (2008) have proposed an equation that expresses the parameter $\mathrm{k}$ in equation 2 as a function of the water to cement ratio $\mathrm{W} / \mathrm{C}$ :

$$
k=k_{0} \ln \left(8.6 \frac{w}{c}\right)
$$

The parameter $k_{0}$ in this equation takes into account of the size of the aggregates, the volume of cement paste and the tortuosity effect of aggregates (Nguyen et al., 2006). The size of the aggregates is not indicated by Brooks. The cement paste volume varies from $30 \%$ to $40 \%$ with the increase of the water to cement ratio. There is certainly a slight effect of this very parameter on $k_{0}$ but this effect is lower than the effect of the W/C. Finally a constant value is assumed for $k_{0}$ and is adjusted to a value of 0.1 in line with the Brooks' tests.

The simulation of the Brooks' tests assumes that, based on Equation 1, the value of the basic creep parameters can be established on the initial part of the curves i.e. before 1000 days (figure 2). This assumption certainly introduces a bias because leaching 
occurs since the sample is placed in the tank. This approach may conduct to an overestimation of the effect of leaching on the long term. Nevertheless the assumption seems acceptable considering the objective of the analysis i.e. to see if the leaching phenomenon could explain the observed behavior. Table 1 gives the basic creep parameters for the tests we have used. The values of these parameters are comparable with values obtained from the RILEM database (Torrenti et Leroy, 2017). Beyond this time limit, leaching must be taken into account by recalculating the stress at each time step and applying the principle of superposition. Figure 3 shows that the leaching, with a set of parameters that is compatible with those found in the literature, explains the non-linearity of the basic creep in the very long term.

Table 1. Parameters of the basic creep for Brooks tests.

\begin{tabular}{|c|c|c|}
\hline W/C & $\beta_{1 . C}$ & $\beta_{2}$ \\
\hline 0.8 & 0.025 & 1 \\
\hline 0.67 & 0.037 & 1 \\
\hline 0.58 & 0.055 & 1 \\
\hline 0.54 & 0.070 & 1 \\
\hline 0.5 & 0.080 & \\
\hline
\end{tabular}

Figure 3. Comparison of Brooks' experimental results and creep modeling taking into account the leaching of concrete. $k_{0}=0.1$.

\section{Conclusions}

The basic creep of the concrete can be expressed as a logarithmic function of the time that has elapsed since the start of loading. Differences observed in the very long term in laboratories tests, namely the acceleration of creep after 1000 days, can be explained by other physical phenomena related to the storage conditions: undesired 
drying in the case of preservation under a water-tight coating and leaching in the case of storage in water. In the latter case, a simple leaching model and the use of the superposition principle for creep have been applied to show that observed behaviour can be reproduced with a plausible set of parameters.

Concerning long term testing of basic creep, in the case of storage in water it seems preferable to keep the same storage water during the test to avoid leaching. A verification of the leached zone at the end of the test is also useful. When a sealed sample is used, if the mass loss could not be avoided, the measurement of the mass variation could allow by an inverse analysis to correct the effect of drying on the basic creep. This inverse analysis needs a complete coupled model for delayed strains of concrete. 


\section{References}

Aili A., Vandamme M., Torrenti J.M., Masson B. (2018). Is long-term autogenous shrinkage a creep phenomenon induced by capillary effects due to selfdesiccation?, Cement and Concrete Research, accepted for publication.

Attolou A., Belloc A., Torrenti J.M. (1989). Méthodologie pour une nouvelle protection du béton vis à vis de la dessiccation, Bulletin de Liaison des LPC, $\mathrm{n}^{\circ} 164$, p. 8586 (in French).

Barthelemy J.F., Sellin J.P., Torrenti J.M. (2015). The effects of long term behavior of both concrete and prestressing tendons on the delayed deflection of a prestressed structure, Concreep10 conference, Vienna.

Bažant Z.P., Hubler M.H., Yu Q. (August 2011). Excessive Creep Deflections: An Awakening, Concrete International, p. 44-46.

Benboudjema F., Meftah F., Torrenti J.-M. (2005). Interaction between drying, shrinkage, creep and cracking phenomena in concrete, Eng. Structures, 27, p. 239-250.

Benboudjema F., Torrenti J.M. (2015). On the very long term delayed behaviour of biaxially prestressed structures: the case of the containments of nuclear power plants, Concreep10 conference, Vienna.

Brooks J J (2005) 30-Year creep and shrinkage of concrete. Mag. Concr. Res. 57(9), p. $545-556$

Charpin L., Le Pape Y., Coustabeau E., Toppani E., Heinfling G., Le Bellego C., Masson B., Montalvo J., Courtois A., Sanahuja J., Reviron N. (2018). A 12 year EDF study of concrete creep under uniaxial and biaxial loading, Cement and Concrete research, 103, p. 140-159.

Flatt R.J., Scherer G.W., Bullard J.W. (2011). Why alite stops hydrating below 80\% relative humidity, Cement and Concrete Research 41 p. 987-992

Houst Y.F. (1997). Carbonation shrinkage of hydrated cement paste, 4th CANMET/ACI International Conference on Durability of Concrete, Ottawa, Canada, p. 481-491.

Hubler M.H., Wendner R., Bažant Z.P. (2015). Comprehensive Database for Concrete Creep and Shrinkage: Analysis and Recommendations for Testing and Recording, ACI Materials Journal; 112(4): 547-558.

Kamali S., Moranville M., Leclerq S. (2008). Material and environmental parameter effects on the leaching of cement pastes: Experiments and modelling, Cement and concrete research, 38 (4), p.575-585

Le Roy R., Le Maou F., Torrenti J.M. (2017), Long term basic creep behavior of high performance concrete. Data and modelling, Materials and structures, 50:85, DOI 10.1617/s11527-016-0948-8

Muller, H., Anders, I., Breiner, R., \& Vogel, M. (2013). Concrete: Treatment of types and properties in fib Model Code 2010. Structural Concrete, 14, 320-334

Nguyen V.H., Colina H., Torrenti J.M., Boulay C., Nedjar B. (2007). Chemomechanical coupling behaviour of leached concrete. Part I: Experimental results, Nuclear Engineering and Design 237, p.2083-2089

Nguyen V.H., Nedjar B., Colina H., Torrenti J.M. (2006). A separation of scales omogenization analysis for the modelling of calcium leaching in concrete, Comput. Methods Appl. Mech. Engrg. 195, p.7196-7210. 
Rossi P., Tailhan J.L., Le Maou F., Gaillet L., Martin E. (2012). Basic creep behavior of concretes investigation of the physical mechanisms by using acoustic emission, Cement and Concrete Research 42 p.61-73

Sellin J.P., Barthelémy J.F., Torrenti J.M., Bondonet G. (2014), Delayed deformations of segmental prestressed concrete bridges: the case of the Savines Bridge, Proceedings of the Intern. Conference on Ageing of Materials \& Structures, Delft

Šmilauer V., Leps M. \& Gregorova M. (2013), Updating B3 model for long-term basic creep, Life-Cycle and Sustainability of Civil Infrastructure Systems - Strauss, Frangopol \& Bergmeister (Eds), Taylor \& Francis Group

Torrenti J.M., Nguyen V.H., Colina C., Le Maou F., Benboudjema F., Deleruyelle F. (2008). .Coupling between leaching and creep of concrete, Cement and concrete research, 38 p.816-821.

Torrenti J.M. (2017). Basic creep of concrete - Coupling between high stresses and elevated temperatures, European Journal of Environmental and Civil Engineering, DOI: 10.1080/19648189.2017.1280417

Torrenti J-M, Le Roy R. (2017), Analysis of some basic creep tests on concrete and their implications for modeling. Structural Concrete. https://doi.org/10.1002/suco.201600197

Toutlemonde F., Le Maou F. (1999). Protection des éprouvettes de béton vis-à-vis de la dessiccation - Le point sur quelques techniques de laboratoires. Bulletin des laboratoires des Ponts et Chaussées, 203:105-119

Ulm F.-J., Le Maou F., Boulay C. (1999). Creep and shrinkage couplings: new review of some evidence, Revue Française de génie civil, Ed. Hermès 3, 21-37.

Yssorche M.P., Ollivier J.P. (1999). La microfissuration d'autodessiccation et la durabilité des BHP et BTHP, Materials and Structures, vol. 32, p. 14-21. 